\title{
Historic times for US marijuana policy reform
}

\author{
Cite as: CMAJ 2017 January 16;189:E86-7. doi: 10.1503/cmaj.109-5364
}

$T$ he United States election was a dreadful night for Democrats but a major victory for fans of marijuana. The drug was approved for recreational use in California, Nevada and Massachusetts. Maine also narrowly approved the recreational use of pot, though that result remains uncertain pending a vote recount. Voters in Arkansas, Florida and North Dakota endorsed the use of cannabis for medical purposes, and Montana lifted restrictions on its medicalmarijuana law.

But it wasn't all good news for marijuana advocates: $52 \%$ of voters in Arizona rejected a proposed legalization measure. Overall, however, it was perceived as a historic night by advocates of softening pot prohibition laws they see as outdated.

"November 8 was the most important day in the history of the marijuana policy reform movement," Tom Angell, chairman of the marijuana reform group Marijuana Majority, said in an email. "But even though we've enjoyed so much success at the state level, including in the South, federal prohibition stands in the way of full and effective implementation of local policies."

Drug Policy Alliance, an organization that promotes drug policies that are "grounded in science, compassion, health and human rights," referred to election night as a "watershed moment for the movement to end marijuana prohibition." When contacted for comment by CMAJ, Tony Newman, director of media relations for the organization, forwarded a statement that read, in part: "By shifting away from counterproductive marijuana arrests and focusing instead on public health, states that have legalized marijuana are diminishing many of the worst harms of the war on drugs, while managing to raise substantial revenues."

For opponents of expanding marijuana use, who see the push for pot legalization as a profit-driven movement, at the expense of the health of US citizens, the results were disappointing.

"These initiatives were written by, to, and for the marijuana industry. California's law will allow for pot advertising, which is astonishing given that we banned cigarette ads 40 years ago from television," Kevin Sabet, president and CEO of Smart Approaches to Marijuana, a group that opposes legalization, said in an email. "Make no mistake: these laws do nothing but help the Big Marijuana industry take hold and make more money."

Just two years ago, a proposal for medical marijuana in Florida received only $58 \%$ support, below the $60 \%$ required to pass. On Nov, 8 , however, support grew to a decisive $71 \%$. Voters in North Dakota were not as eager as those in Florida to allow patients access to pot, but the final tally of $64 \%$ was enough to approve the proposed measure.

The result in Florida was welcome news for marijuana advocates. Prior to the election, medical marijuana was already legal in 25 states, but none were in the South. The decisive vote in Florida is seen by some as an indicator that the South is changing its attitude about using cannabis in health care.

Legalization of marijuana in California, in particular, is considered by many to be a major step toward nationwide reform in the US. The state has a massive population ( $12 \%$ of all Americans live there) and a correspondingly large economy. The potential economic impact of a flourishing cannabis industry may be hard to ignore at the federal level. By some estimates, California stands to reap more than $\$ 1.2$ billion in taxes on marijuana.

Still, there are concerns that the administration of incoming US President Donald Trump will push back on statelevel marijuana reforms. Though Trump has not been a vocal opponent of marijuana, some of the people he has nominated for his administration haven't been as quiet on the issue. In a recent Senate hearing, the nominee for US Attorney General, Senator Jeff Sessions of Alabama, said that "good people don't

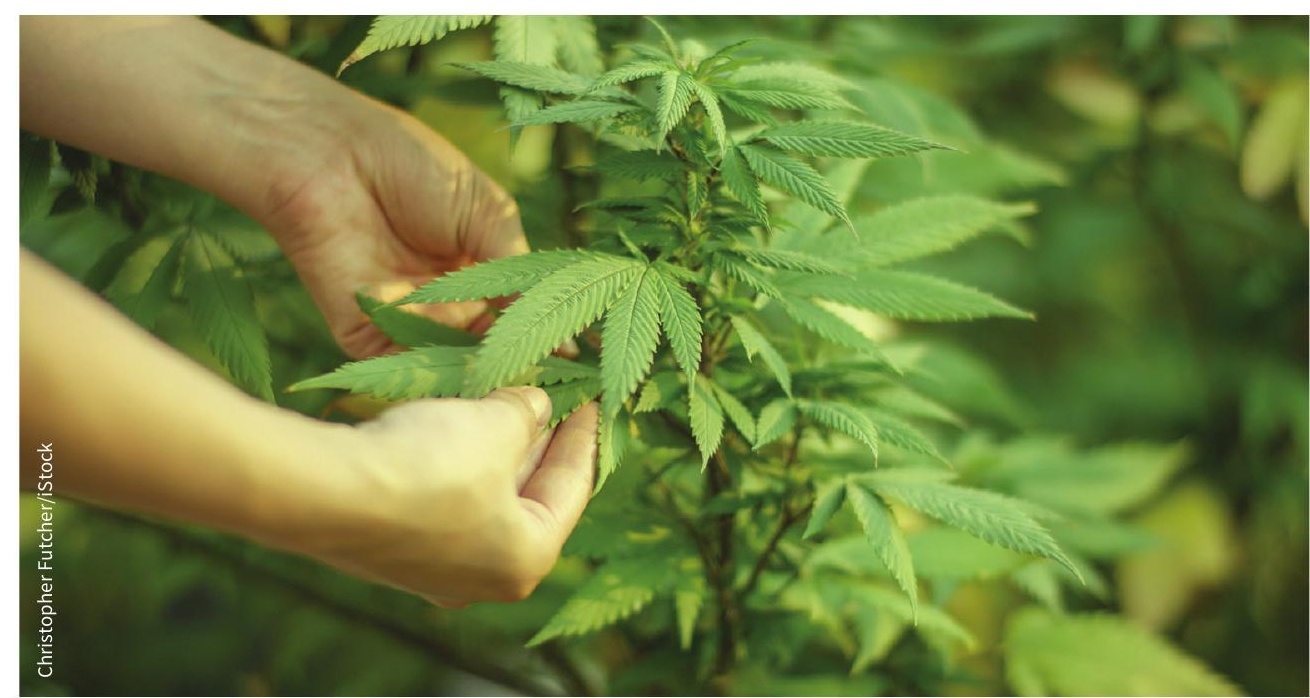

Marijuana for medical use is now legal in 29 states in the United States. 
smoke marijuana," adding that "this drug is dangerous; you cannot play with it."

Though the choice to nominate Sessions certainly isn't good news for marijuana reform, Angell of Marijuana Majority is still hopeful the new administration will realize that a crackdown against broadly popular laws in a growing number of states would create backlash and political headaches. "The truth is, mari- juana reform is much more popular with voters than most politicians, and officials in the new administration would do well to take a careful look at polling data on the issue before deciding what to do," he said.

According to Sabet, however, the incoming Attorney General should enforce federal laws that prohibit marijuana, regardless of state-level legaliza- tion measures. "The issue is really as simple as stating that federal law is, in fact, the law of the land and will be enforced across the entire nation," he said. "There is a long and winding road to whatever ends up happening in the US. Legalization may have made some gains, but there were some losses as well."

Roger Collier, CMAJ 